\title{
Diuretic induced gout: a multifactorial condition
}

\author{
J T Scott, C S Higgens
}

\begin{abstract}
Fifteen patients with clinical gout occurring after long term treatment with diuretics were studied retrospectively. In all 15 patients one or more additional factors were present which might have contributed to the hyperuricaemia and gout. The most common of these was the impairment of the glomerular filtration rate.

Twenty five other patients receiving long term treatment with diuretics who did not have gout were also studied. The concentrations of uric acid, urea, and creatinine were, in general, markedly lower in these patients than in those who had developed gout.
\end{abstract}

It is concluded that diuretic induced gout occurs in patients in whom there is an additional cause of hyperuricaemia, usually impaired renal function.

Diuretics are now the most commonly prescribed drugs for elderly patients. ${ }^{1}$ They are a well recognised cause of secondary hyperuricaemia and gout, reducing the excretion of urate by complex effects on the renal tubule. ${ }^{2}$ It is increasingly apparent that hyperuricaemia and gout often result from a combination of factors, genetic and environmental. This study examines the extent to which additional influences may be contributing to the hyperuricaemia of diuretic induced gout.

\section{Patients and methods}

The records were examined of 15 personally observed patients in whom a diagnosis of diuretic induced gout had been made. This was based on a typical clinical history of attacks of acute gouty arthritis, except in two patients in whom crystal proven tophi were present in the absence of acute attacks. Three of the patients were seen during an attack and urate crystals were identified in their joint fluid by polarised light microscopy.

Eight of the patients were women and seven were men, aged from 56 to 89 years (mean 72 years). The duration of treatment with diuretics ranged from two to 15 years (mean 6.5 years), the usual indication for the drug being hypertension. Various combinations of the commonly prescribed benzothiadiazine or loop diuretics had been used. Gout took the form of acute attacks only (ten patients), chronic tophi alone (two patients) or the two in combination (three patients). All subjects were markedly hyperuricaemic.

The patients were examined for the presence of any other factors which might have been contributing to an increased concentration of uric acid, namely impairment of renal function (as seen by increased concentrations of urea or creatinine in plasma), a family history of gout or the presence of any disorder which could have predisposed to hyperuricaemia.

Twenty five other patients receiving long term treatment with diuretics who did not have gout were also studied. Fourteen were men and 11 women, aged from 60 to 85 years (mean 73 years). The duration of treatment with diuretics ranged from one to 17 years (mean six years).

Plasma concentrations of uric acid, urea, and creatinine were determined by routine methods on a hospital multichannel analyser.

\section{Results}

Table 1 gives details of the 15 patients with diuretic induced gout. All patients had another condition which could have contributed to hyperuricaemia, usually an impaired glomerular

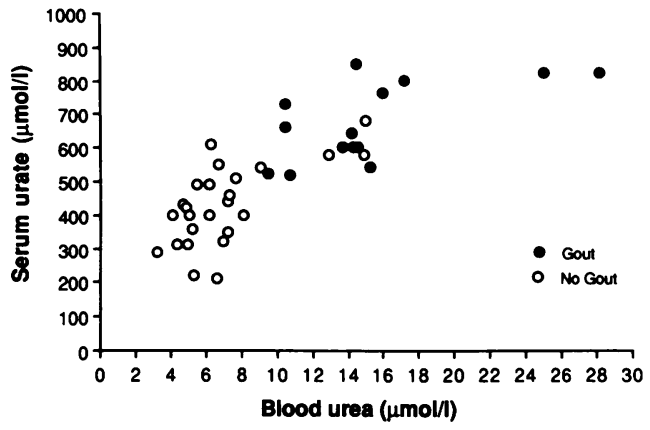

Figure 1 Concentrations of uric acid and urea in 39 patients, with and without gout, receiving long term treatment with diuretics.

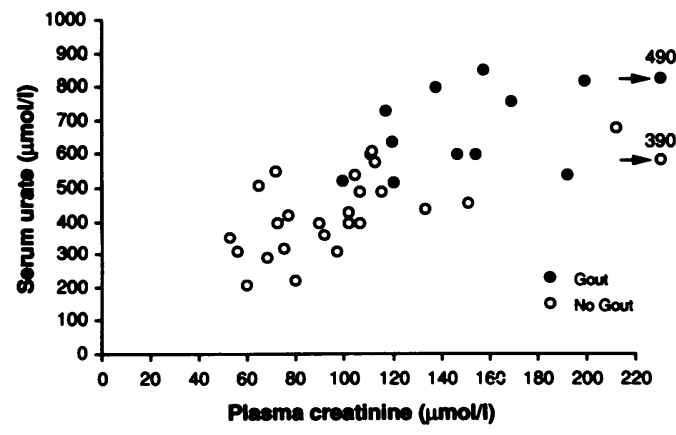

Figure 2 Concentrations of uric acid and creatinine in 38 patients, with and without gout, receiving long term treatment with diuretics. (One patient included in fig 1 was not analysed for creatinine). 
Table 1 Clinical details of 15 patients with diuretic induced gout

\begin{tabular}{|c|c|c|c|c|c|c|c|c|c|c|c|c|c|}
\hline $\begin{array}{l}\text { Patient/ } \\
\text { sex }\end{array}$ & $\begin{array}{l}\text { Date of } \\
\text { birth }\end{array}$ & $\begin{array}{l}\text { Diuretic } \\
\text { prescribed }\end{array}$ & $\begin{array}{l}\text { Age at } \\
\text { which gout } \\
\text { first diag- } \\
\text { nosed (years) }\end{array}$ & $\begin{array}{l}\text { Duration of } \\
\text { treatment } \\
\text { with diuretic } \\
\text { (vears) }\end{array}$ & $\begin{array}{l}\text { Reason for } \\
\text { diuretic }\end{array}$ & $\begin{array}{l}\text { Acute } \\
\text { attacks }\end{array}$ & Tophi & Crystals & $\begin{array}{l}\text { Urea } \\
(\text { mmoll } l)\end{array}$ & $\begin{array}{l}\text { Creatinine } \\
\text { (1 tmollil) }\end{array}$ & $\begin{array}{l}\text { Uric acid } \\
(\text { (!molll })\end{array}$ & $\begin{array}{l}\text { Family } \\
\text { history }\end{array}$ & $\begin{array}{l}\text { Other } \\
\text { factors }\end{array}$ \\
\hline $1 \mathrm{~F}$ & 13 August 1920 & Cyclopenthiazide & 63 & 10 & $\begin{array}{l}\text { Myocardial } \\
\text { ischaemia }\end{array}$ & + & 0 & ○ & $10 \cdot 5$ & 118 & 730 & 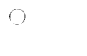 & \\
\hline $2 \mathrm{M}$ & 19 May 1923 & $\begin{array}{l}\text { Cyclopenthiazide } \\
\text { Frusemide } \\
\text { Methyldopa }\end{array}$ & 56 & 5 & $\begin{array}{l}\text { Hypertension } \\
\text { Myocardial } \\
\text { infarct }\end{array}$ & + & 0 & + & $28 \cdot 2$ & 200 & 820 & $\rho$ & $\begin{array}{l}\text { Polycy- } \\
\text { thaemia } \\
\text { rubra vera }\end{array}$ \\
\hline $3 \mathrm{~F}$ & 13 September 1913 & $\begin{array}{l}\text { Chlorthalidone } \\
\text { Frusemide } \\
\text { Amiloride }\end{array}$ & 74 & 7 & Hypertension & + & 0 & 0 & $14 \cdot 6$ & 147 & 600 & $\sigma$ & \\
\hline $4 \mathrm{~F}$ & 21 August 1899 & $\begin{array}{l}\text { Frusemide } \\
\text { Amiloride }\end{array}$ & 89 & 4 & Heart failure & 0 & + & + & $17 \cdot 2$ & 138 & 800 & 0 & \\
\hline $5 M$ & 3 July 1905 & Frusemide & 82 & 6 & Heart failure & + & 0 & O & $13 \cdot 7$ & 111 & 600 & 0 & \\
\hline $6 \mathrm{M}$ & 18 June 1910 & $\begin{array}{l}\text { Frusemide } \\
\text { Spironolactone }\end{array}$ & 76 & 6 & $\begin{array}{l}\text { Myocardial } \\
\text { infarct }\end{array}$ & + & 0 & 0 & $15 \cdot 3$ & 193 & 540 & 0 & $\begin{array}{l}\text { Polycy- } \\
\text { thaemia } \\
\text { rubra vera }\end{array}$ \\
\hline $7 \mathrm{M}$ & 12 June 1912 & $\begin{array}{l}\text { Hydrochlorthiazide } \\
\text { Amiloride }\end{array}$ & 74 & $?$ & $?$ & + & + & + & $16 \cdot 0$ & 170 & 760 & 0 & \\
\hline $8 \mathrm{~F}$ & 20 August 1917 & $\begin{array}{l}\text { Hydrochlorthiazide } \\
\text { Triamterine }\end{array}$ & 71 & 3 & Hypertension & 0 & + & + & $14 \cdot 3$ & 155 & 600 & 0 & \\
\hline $9 \mathrm{~F}$ & 1 March 1914 & Cyclopenthiazide & 74 & $?$ & Hypertension & + & 0 & + & $14 \cdot 2$ & 120 & 640 & 0 & \\
\hline $10 \mathrm{~F}$ & 3 September 1913 & $\begin{array}{l}\text { Frusemide } \\
\text { and others }\end{array}$ & 70 & 6 & Hypertension & + & 0 & 0 & $6 \cdot 2$ & & $\begin{array}{l}\text { No pre- } \\
\text { treatment } \\
\text { level }\end{array}$ & + & $\begin{array}{l}\text { Brother } \\
\text { with gout }\end{array}$ \\
\hline $11 \mathrm{~F}$ & 14 April 1901 & Cyclopenthiazide & 82 & 5 & Hypertension & + & + & 0 & $9 \cdot 5$ & 100 & 525 & 0 & $\begin{array}{l}\text { Hypo- } \\
\text { thyroidism }\end{array}$ \\
\hline $12 \mathrm{~F}$ & 4 April 1926 & $\begin{array}{l}\text { Chlorothiazide } \\
\text { Cyclopenthiazide } \\
\text { Frusemide } \\
\text { Amiloride }\end{array}$ & 56 & 9 & $\begin{array}{l}\text { Hypertension } \\
\text { Obesity } \\
\text { Oedema }\end{array}$ & + & + & 0 & $14 \cdot 5$ & 158 & 850 & + & \\
\hline $13 M$ & 1922 & Chlorthalidone & 67 & 10 & Hypertension & + & 0 & 0 & $10 \cdot 7$ & & 520 & 0 & \\
\hline $14 M$ & 1907 & Frusemide & 83 & 15 & Hypertension & + & O & 0 & $10 \cdot 5$ & 121 & 666 & 0 & \\
\hline $15 \mathrm{M}$ & 16 June 1931 & $\begin{array}{l}\text { Frusemide } \\
\text { Bendrofluazide }\end{array}$ & 54 & 6 & Hypertension & + & 0 & 0 & $25 \cdot 0$ & 490 & 820 & 0 & \\
\hline
\end{tabular}

Table 2 Comparison of the concentrations of uric acid, urea, and creatinine in plasma of patients with and without gout receiving long term treatment with diuretics. Values given are mean $(S D)$

\begin{tabular}{llll}
\hline $\begin{array}{l}\text { Concentrations in } \\
\text { plasma }\end{array}$ & $\begin{array}{l}\text { Patients with } \\
\text { gout }\end{array}$ & $\begin{array}{l}\text { Patients without } \\
\text { gout }\end{array}$ & p Value \\
\hline Urate $(\mu \mathrm{mol} / \mathrm{l})$ & $676 \cdot 1(118 \cdot 2)$ & $430 \cdot 0(120 \cdot 6)$ & $<0 \cdot 001$ \\
Urea $(\mathrm{mmol} / \mathrm{l})$ & $15 \cdot 3(5 \cdot 3)$ & $7 \cdot 0(3 \cdot 1)$ & $<0 \cdot 001$ \\
Creatinine $(\mu \mathrm{mol} / \mathrm{l})$ & $218 \cdot 5(206 \cdot 7)$ & $108 \cdot 4(68 \cdot 0)$ & $<0 \cdot 02$ \\
\hline
\end{tabular}

filtration rate as seen by concentrations of urea or creatinine in plasma above the upper limits of normal subjects for our laboratory $(6.5 \mathrm{mmol} / 1$ and $130 \mu \mathrm{mol} / \mathrm{l}$, respectively) in 14 patients; a family history of gout in two patients, a history of polycythaemia rubra vera in two patients, and hypothyroidism in one patient.

Concentrations of uric acid, urea, and creatinine were usually markedly lower in the 25 patients who did not have gout than in the patients with gout (table 2, figs 1 and 2). None was known to have a family history of gout or a history of a blood dyscrasia.

\section{Discussion}

Although hyperuricaemia is sometimes attributable to a single cause, such as deficiency of the enzyme HGPRTase causing gross overproduction of urate in the Lesch-Nyhan syndrome, experience with patients with gout indicates that very often more than one mechanism is operating. Every doctor is familiar with the patient who has a strong family history of gout (indicating the likelihood of a genetic factor) and who eats and drinks too much, adding environmental influences which contribute to hyperuricaemia. Even in situations where there appears to be only one operative cause the position may not be so simple. For example, the hyperuricaemia accompanying polycythaemia rubra vera is generally accepted to be secondary to the overproduction of nucleoprotein resulting from a proliferative disorder of red cell precursors. Denman et $a l^{3}$, however, found that the high concentrations of urate and the occurrence of clinical gout tended to be associated with renal failure rather than with the increase in the number of platelets, megakaryocyte proliferation, or myelofibrosis.

A comparable position exists with regard to diuretic induced hyperuricaemia and gout. There is no doubt that benzothiadiazine and loop diuretics are potent agents causing the retention of urate, but all 15 patients with gout studied here showed one or more additional features which may have been contributing to hyperuricaemia.

Of these, impairment of the glomerular filtration rate was the most common, being present, as assessed by increased concentrations of urea or creatinine in plasma, in 14 patients, sometimes mild and sometimes marked. There is an overall relation between uric acid clearance and glomerular filtration rate. Urate clearance falls with the glomerular filtration rate, although with renal failure there is a relative increase in fractional urate excretion, i.e. as the number of functioning nephrons falls, there is an increase in the excretion of urate per nephron. ${ }^{4}$ Never- 
theless, the absolute value for the 24 hour urinary excretion decreases with decreases in the glomerular filtration rate. ${ }^{5}$

The myeloproliferative disorder polycythaemia rubra vera was present in two patients. To what extent urate overproduction was present and contributing to hyperuricaemia is unknown. Those two patients showed definite evidence of renal failure. One further patient had been treated for hypothyroidism, a condition which has been associated with hyperuricaemia, ${ }^{6}$ though this is contentious. ${ }^{78}$

Two patients had a family history of gout; one had evidence of an impaired glomerular filtration rate, and the other had a normal renal function as seen by a normal concentration of urea in blood. Relatives of patients with gout have significantly higher values of serum urate than controls ${ }^{10}$ and it is possible that these two patients had been hyperuricaemic before the effect of the diuretics was added.

It is conceded that a retrospective study of this type has certain limitations. First, the diagnosis of gout was confirmed in only five patients by the identification of urate crystals in joint fluid or from tophi. Many now regard such identification as almost mandatory in making a diagnosis of gout. However, very careful histories were taken and the investigators feel little doubt that the diagnosis was correct.

Second, estimates of renal function (plasma urea and creatinine) were carried out only after the patients had been receiving diuretics for a long time, and we have no knowledge of renal function before the treatment began. Urea and creatinine concentrations are crude measurements of the glomerular filtration rate. To what extent their increase was associated with underlying disease (usually hypertension) or to what extent other factors were contributing, including a possible effect of the diuretics themselves, is uncertain. Moreover, the patients were elderly and the glomerular filtration rate is known to decrease with increasing age in the absence of disease. ${ }^{11} 12$ It remains steady until the age of 50 years and then decreases, so that by 80 years there is a decrease of about $40 \%$. A moderate increase in the concentration of urea and creatinine may therefore be of doubtful significance in elderly patients.
There are nevertheless striking differences in the concentrations of urea and creatine (and also urate) in plasma between the 15 patients with gout and the larger group who did not have gout. A comparison between the two groups appears justified because their ages and the duration of treatment with diuretics are closely similar. It therefore appears that the patients in whom gout developed had various degrees of renal functional impairment and that this contributed substantially to a much greater degree of hyperuricaemia than that seen in the patients who did not develop gout. Indeed, taking a concentration of $420 \mu \mathrm{mol} / \mathrm{l}$ as an upper limit of normal uric acid, all the patients with gout were markedly hyperuricaemic whereas only 12 of the other 25 patients had concentrations greater than this. The higher concentrations of uric acid were consequentially expressed by the appearance of clinical gout.

From this it may be inferred that patients receiving long term treatment with diuretics who maintain normal renal function, and who do not have any other condition predisposing to hyperuricaemia, are unlikely to develop diuretic induced gout.

1 Williamson J, Chopin J M. Adverse reactions to prescribed drugs in the elderly: a multicentre investigation. Age Ageing 1980; 9: 73-80.

2 Scott J T. Drug-induced gout. Baillieres Clin Rheumatol 1991; 5: 39-60.

3 Denman A M, Szur L, Ansell B M. Joint complaints in penman A M, Szur L, Ansell B M. Joint complaint
polycythaemia vera. Ann Rheum Dis 1964; 23: 139-44.

4 Steele T H, Rieselbach R E. The contribution of residual nephrons within the chronically diseased kidney to urate homeostasis in man. Am F Med 1967; 43: 876-86.

5 Emmerson B T, Row P G. An evaluation of the pathogenesis of the gouty kidney. Kidney Int 1975; 8: 65-71.

6 Leeper R D, Benua R S, Bremer J L, Rawson R W Hyperuricaemia in myxoedema. $\mathcal{F}$ Clin Endocrinol 1960; 20 1457-66.

7 Boyle H A, Greig W R, Duncan A M, Boyle I T, Buchanan $W W$. Serum uric acid values in various states of thyroid function. Acta Rheum Scand 1966; 12: 204-9.

8 Golding D N. Hypothyroidism presenting with musculoskeletal symptoms. Ann Rheum Dis 1970; 29: 10-4.

9 Hauge $M$, Harvald B. Heredity in gout and hyperuricaemia. Acta Med Scand 1955; 152: 247-57.

10 Scott J T, Pollard A C. Uric acid excretion in the relatives of patients with gout. Ann Rheum Dis 1970; 29: 397-400.

11 Davies D F, Shock N W. Age changes in glomerular filtration rate, effective renal plasma flow and tubular excretory capacity in adult males. 7 Clin Invest 1950; 29: 496-507.

12 Rowe J W, Andres R, Tobin J D, Norris A H, Shock N W. The effect of age on creatinine clearance in men: a crosssectional and longitudinal study. $\mathcal{F}$ Gerontol 1976; 31: 155-63. 